\title{
Principal Supervision and Teacher Performance in Public Elementary Schools
}

\author{
Ai Rohartini ${ }^{1,2 *}$, Cicih Sutarsih ${ }^{1}$ \\ ${ }^{1}$ Educational Administration Department, ${ }^{2}$ Headmaster Elementary School Anjun 2 \\ ${ }^{1}$ Universitas Pendidikan Indonesia \\ ${ }^{1}$ Bandung, ${ }^{2}$ Purwakarta, Indonesia \\ *rohartiniai76@gmail.com
}

\begin{abstract}
Supervision has an important role in building teacher professionalism that is realized in the form of improving teacher teaching performance in schools. This research tries to dig deeper into the contribution of supervision by the principal to the teaching performance of teachers in elementary schools. This study uses a quantitative descriptive approach. The data was obtained through purposive distribution of questionnaires to 78 teachers from 26 public elementary schools in Plered SubDistrict, Purwakarta Regency. The data obtained is then processed with regression to gain the amount of influence from the supervision of the principal on the teacher's performance. The results showed that the supervision conducted by the principal can improve the performance of teachers. These results mean that the teacher's performance can continue to be improved as long as the principal performs his duties as a well supervised.
\end{abstract}

Keywords-elementary school, principal supervision, teaching performance

\section{INTRODUCTION}

The teacher is an important figure in the aspects of the learning process. The teacher acts as a person who is able to educate and provide knowledge to students so that they have abilities and skills that are beneficial to society. Therefore, a teacher must have a good teaching performance for the success of their students. Qualified students are determined by the quality learning process. The process must be handled by teachers who are professional and of high integrity.

The results of the quality report card for SD Negeri 2 Anjun below show that the standard of educators and education in the last 3 years shows that the average score has not increased and even tends to be static, still at a score of 3.52 to 3.59 which is at the SNP level 3. This shows the need for serious improvements for educators to jointly improve their performance in order to develop the quality of learning in schools [1].

Problems regarding teachers, especially teacher performance, are problems that are often scrutinized and dynamic. Several research studies show a relationship between teacher teaching performance and the supervisory competence of school principals and school climate [2-4].

The success of education in schools is determined by the success of a leader, namely the principal. The principal is responsible for organizing educational activities, schoo administration, fostering education and education personnel, and making use of school resources. The principal is one component in improving teacher performance. The leadership of the principal has an impact on capacity and can develop teacher quality and improve teacher competencies, so that it has a positive impact in the learning process. One of the actions implemented in advancing education in Indonesia is by fostering school principals who are not only competent in one field but competent in another [5].

One of the competencies that must be possessed by the principal is competence as a supervisor. As a supervisor, he is responsible for and plays a role in helping teachers to improve the professionalism of their performance in providing lessons to students optimally. Supervision is a service technique whose main purpose is to study and improve together the factors that affect children's growth and development [6]. To carry out supervision effectively requires conceptual, interpersonal and technical skills [7]. Therefore, every principal must have and master the concept of academic supervision which includes: definition, purpose and function, principles, and the substance dimensions of academic supervision.

The supervision applied by the principal is certainly very effective, because it can provide assistance, guidance and guidance to teachers so that they are able to work better in guiding students and can improve their performance in improving learning in schools[8]. With the supervision of the principal, it will have an effect on improving teacher performance [9].

Continuous supervision activities are needed to improve teacher performance. So that, they are able to prioritize aspects of learning achievement for their students. Supervision activities are intended to determine the extent of the implementation of the duties and obligations of the teachers and to listen to the difficulties of the teachers in carrying out 
their main duties, so that efforts to solve the problem can be sought. By implementing effective supervision and paying attention to the principles, it is hoped that it can improve teacher performance so that educational goals can be achieved properly.

The issuance of Regulation of the Minister of National Education Number 13 of 2007 concerning Principal Standards for Schools/Madrasahs has a logical implication that the principal as the highest leader in schools is required to have five competency dimensions, namely the dimensions of personality, managerial, entrepreneurial, supervisory and social competencies. The operationalization of Government Regulation Number 13 of 2007 is regulated through the Regulation of the Minister of National Education Number 28 of 2010 concerning the Assignment of Teachers as Principals of Schools/Madrasas which outlines the requirements and stages that must be passed by a teacher to be given additional duties as principal of schools/madrasah (Ministry of Education, 2011).

\section{METHODS}

This study uses descriptive methods to provide a systematic, factual, and accurate description of the factors, facts, and characteristics and relationships between the currently studied phenomena. The purpose of this study was to examine the magnitude of the effect of principal supervision on teacher performance at a number of public elementary schools in Plered District, Purwakarta Regency.

Through a purposive sampling technique of 644 teachers, it was obtained that 78 teachers were respondents from 26 existing public elementary schools. Data obtained through distributing closed questionnaires to respondents by providing a scale to the answers given. Principal supervision is measured from three dimensions: principles of supervision, practices of supervision, and outcome of supervision. Meanwhile, teacher performance is measured through cognitive activation, classroom management and clarity of instruction, and student support. The data analysis technique uses linear regression to obtain the magnitude of the effect of the implementation of principal supervision on teacher performance.

\section{RESULTS AND DISCUSSION}

The findings of a number of literatures explain that school principal supervision has an effect on improving teacher performance. This is what researchers are trying to prove by conducting a regression test of the data that has been collected. This test is performed with a simple regression technique using the IBM SPSS 26. From the results of the tests performed, the results are as described in the table 1 below.
TABLE I. REGRESSION TEST

\begin{tabular}{|l|l|l|l|l|c|}
\hline \multirow{2}{*}{ Model } & \multicolumn{2}{|c|}{$\begin{array}{c}\text { Unstandardized } \\
\text { Coefficients }\end{array}$} & $\begin{array}{c}\text { Standardized } \\
\text { Coefficients }\end{array}$ & \multirow{2}{*}{ Sig. } \\
\cline { 2 - 5 } & B & Std. Error & Beta & & \\
\hline 1 (Constant) & 2.317 & .949 & & 2.441 & .017 \\
\hline $\begin{array}{l}\text { Principal } \\
\text { Supervision }\end{array}$ & .807 & .075 & .775 & 10.695 & .000 \\
\hline \multicolumn{6}{|c|}{ Dependent Variable: Teacher Performance } \\
\hline
\end{tabular}

The results of testing the effect of principal supervision on teacher performance as shown in the table above show a significant and positive effect. The $\mathrm{t}$ test results show the magnitude of the number 10.695 where the number is significant below 0.05 . In terms of regression coefficients, with constant values of 2.317 and 0.807 , it can be explained that an increase in the coefficient of principal supervision by 0.807 will increase teacher performance by 2.317 . If you look at the magnitude of the coefficient value, principal supervision provides a large and significant effect so far. To obtain an exact picture, the researcher then carried out a determination test to obtain the level of determination from principal supervision on teacher performance. These results are presented in the following table 2 .

TABLE II. R-SQUARE TEST

\begin{tabular}{|l|c|c|l|l|}
\hline Model & R & $\begin{array}{c}\text { R } \\
\text { Square }\end{array}$ & $\begin{array}{c}\text { Adjusted } \\
\text { R Square }\end{array}$ & $\begin{array}{c}\text { Std. Error } \\
\text { of the Estimate }\end{array}$ \\
\hline 1 & $.775 \mathrm{a}$ & .601 & .596 & 1.48281 \\
\hline \multicolumn{4}{|c|}{ a. Predictors: (Constant), Principal Supervision }
\end{tabular}

From the test results above, the $\mathrm{R}$ square column obtained the value of 0.601 or $60.1 \%$ if presented. This percentage is sufficient to explain that teacher performance improvement in primary school teachers has been strongly determined by the implementation of principal supervision. These results at the same time also reinforce previous studies that examined the same topic that teacher performance is closely related to the implementation of supervision in schools.

The results of the above study reinforce previous studies that the implementation of principal supervision can improve teacher performance than teachers. The implementation of supervision by the principal will make the supervision activities more intensive because of the principal's understanding of the needs of teachers. The main mission of education supervision is to provide services to teachers to develop the quality of lessons, facilitating teachers to be able to teach effectively. The term learning supervision refers to the understanding of improving the quality of basic activities in schools, namely improving the learning process of teaching or learning [10].

The development of educational supervision develops in line with the development of science, technology, as well as socioeconomic and cultural communities. Supervision moves from the form of inspection where the authority is more dominated by supervisors, develops in the form of collaboration between supervisors and teachers together with 
initiative and is responsible in improving the quality of learning, as well as fostering a culture of learning in teachers to always improve their competence.

Supervision is an effort to stimulate, coordinate and guide the continuous growth of teachers in schools both individually and collectively, in order to better understand and be more effective in realizing all learning functions so that they can stimulate and guide the growth of each student, thus they able and more competent to participate in a modern democratic society [11].

Supervision has an assessment function, namely the assessment of teacher performance by collecting information and facts about teacher performance by conducting research. This evaluation and research activity is an effort to improve so that based on the data and information obtained by supervisors, teacher performance can be improved accordingly and ultimately can improve the quality of teacher performance in carrying out teaching assignments. As a leader, the principal has a duty to mobilize all existing resources in school so that they can be empowered to be used optimally in order to achieve predetermined goals. Whether or not the performance of teachers in school really depends on how the principal's ability to influence teacher behavior in carrying out their duties.

The cause of low teacher performance could be due to the weak supervision process carried out by the school principal. Supervision can improve or even improve the quality of learning. Therefore, it is necessary to have supervision. The low performance of teachers in general which can have a negative impact on student learning outcomes can be seen from several conditions such as the following, there are teachers who work outside working hours on the pretext of meeting daily needs which results in a lack of time spent reading and doing activities that can improve teacher skills; finding teachers who do not carry out teaching and learning activities without any clarity; lack of teacher discipline during working hours; there are still teachers who do not make lesson plans, teachers have not maximized the means of support in delivering the material [9]. Factors that influence the above conditions are communication, organization, principal supervision, work ethic, motivation, teacher welfare, principal leadership and unattended educational facilities which have an impact on unsatisfactory teacher performance.

Good performance can be seen from the results obtained from the assessment of students. Teacher performance is the ability shown by the teacher in carrying out a task or job. Performance is said to be good and satisfying if the objectives are achieved in accordance with predetermined standards. Teacher performance is not only shown by work results, but also by work behavior. So, teacher performance is a condition that shows the ability of a teacher in carrying out his duties at school and describes an act that is displayed by the teacher in or during learning activities.
Supervision is the duty of a principal in teacher coaching through a supervisory function. Supervision carried out by the principal is an assistance in solving the problems faced by teachers in carrying out their duties aimed at fostering and improving aspects of learning, the guidance provided is intended for improvement in teaching not to seek the error of the teaching form carried out by the teacher.

Teachers are the key to the success of the quality of education in this country. As professional teachers also need supervision and guidance in order to improve the implementation of the teaching and learning process they have been doing so far. A teacher who is considered capable of carrying out his duties with the conditions they have fulfilled before they are appointed to become a teacher still needs supervision from various parties. One of them is the supervision carried out by the principal. A school principal should understand his duties and roles in school. If the principal is able to understand his duties and roles as a school principal, he will easily carry out all his duties, especially those related to the supervision he will carry out [12].

As school leaders, in addition to functioning as administrators, principals also function as supervisors, essentially providing professional services in improving the professional competence of teachers and school principals, both directly and indirectly. In the implementation of supervision, the principal can make visits to the class. Checking the teacher's teaching preparation and commenting on the teaching preparation made by the teacher are the duties of the supervisor. Then observe the teaching process and record everything regarding the implementation of learning carried out by the teacher. The principal will then discuss with the teacher the results of his observations; comment on the teacher about what needs to be improved. However, supervision is often carried out only at the stage of examining the lesson plan or the stage of observing the process of implementing teacher learning in class.

\section{CONCLUSION}

The results concluded that the implementation of supervision by the principal had a significant effect on teacher performance in primary school teachers. Teacher performance can be improved through the commitment and consistency of the principal in carrying out supervision, through the process of mentoring and professional assistance. Supervising teachers can be a way for teachers to become independent, innovative and creative in developing their professional skills, resulting in improved student learning outcomes. As a recommendation of this study, the principal needs to maintain the implementation of supervision in the school, in addition to improving his skills in the implementation of supervision as well as new skills that need to be mastered by teachers due to the demands and policies of dynamic education. 


\section{REFERENCES}

[1] Dikdasmen, "PMP Dikdasmen - Penjaminan Mutu Pendidikan Dikdasmen," 2020. Accessed: Oct. 02, 2020. [Online]. Available: http://pmp.kemdikbud.go.id/.

[2] S. Mochamad, "Pengaruh Kompetensi Supervisi Manajerial Dan Supervisi Akademik Pengawas Sekolah Terhadap Kinerja Guru,” J. Ilm. Mhs. Pascasarj. Adm. Pendidik., 2007.

[3] S. Andari, "Kontribusi Manajemen Supervisi Kepala Sekolah, Motivasi Kerja Guru, Dan Iklim Organisasi Terhadap Kinerja Guru Sekolah Dasar," J. Penelit. Ilmu Pendidik., 2015.

[4] I. Sawiyanti, "Pengaruh Iklim Sekolah Terhadap Kinerja Guru di SMP Negeri 1 Ulaweng Kabupaten Bone,” J. Islam. Educ. Manag., 2019.

[5] I. M. D. Wibawa, "Meningkatkan Kinerja Guru dalam Menyusun Silabus dan Rencana Pelaksanaan Pembelajaran (RPP) melalui Supervisi Kolegial,” J. Educ. Action Res., vol. 3, no. 1, pp. 66-71, 2019.

[6] A. W. Schindler, "Supervision (Second Edition) by A. S. Barr, William H. Burton, and Leo J. Brueckner. D. Appleton-Century Company. 879 pp. \$5.00,” Educ. Forum, 1948, doi: 10.1080/00131724809340343.
[7] C. D. Gickman and S. P. Gordon, "Clarifying Developmental Supervision,” Educ. Leadersh., 1987.

[8] N. Ajasan, Nasir U, "Efektivitas Pelaksanaan Supervisi Akademik Oleh Kepala Sekolah Dalam Meningkatkan Kinerja Guru Di SMK Negeri 1 Meulaboh,” J. Adm. Pendidik. Progr. Pascasarj. Unsyiah, 2016.

[9] A. Azainil, I. Sabara, S. Rahayu, R. Ramadiani, and W. Mulawarman, "The Influence of Principal's Supervision Competence and Schoo Culture on Teachers Performance of Public High School in Kutai Kartanegara Regency,” 2020, doi: 10.4108/eai.14-3-2019.2291964.

[10] S. L. Hartati and S. Purba, "The Influences of Principal's Supervision, Teacher's Empowerment, Achievement Motivation on Teacher's Organizational Commitment at the Junior High School,” 2020.

[11] C. C. Chen and T. Y. Chen, "Exploring the relationship among principal's supervision of instruction, teachers' knowledge sharing and teachers' professional development: A test of the mediated-effects model," Cauriensia, 2013.

[12] I. W. Riyadi, W. Karta, and S. Sudirman, “The Influence of School Head Academic Supervision on the Achievement of the National Standards of Middle School Education in Bima City,” Int. J. Multicult. Multireligious Underst., 2019. 